\title{
CD40 Ligand Measurement
}

National Cancer Institute

\section{Source}

National Cancer Institute. CD40 Ligand Measurement. NCI Thesaurus. Code C82007.

The determination of the amount of CD40 ligand present in a sample. 